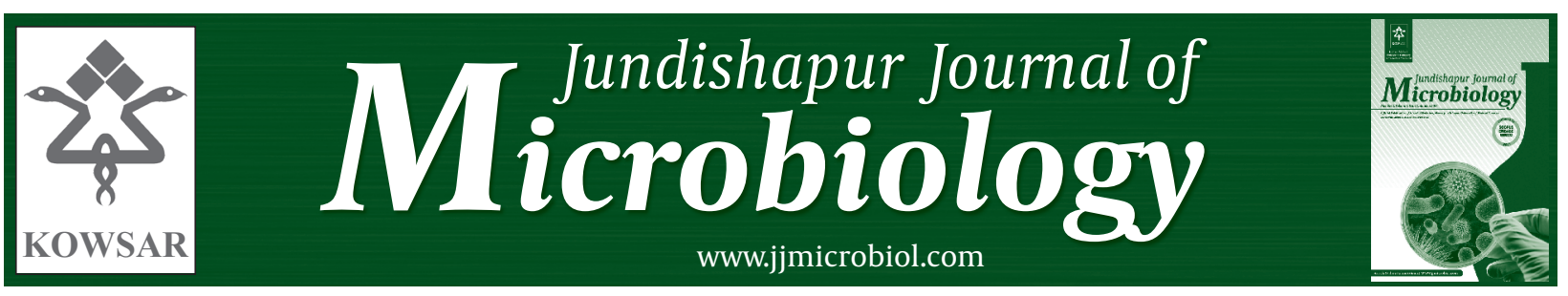

\title{
Prevalence of HTLV-I Infection in Patients with Thalassemia Major in Mazandaran, North of Iran
}

\author{
Javad Ghaffari ${ }^{1}$, Mehrnoush Kowsarian ${ }^{1}$, Mohammad Reza Mahdavi ${ }^{1}$, Koroush Vahid Shahi \\ ${ }^{1}$, Houshang Rafatpanah ${ }^{2}$, Amir Reza Tafreshian ${ }^{2 *}$ \\ ${ }^{1}$ Department of Pediatrics, Mazandaran University of Medical Sciences, Sari, IR Iran \\ ${ }^{2}$ Inflammation and Inflammatory Diseases Research Center, School of Medicine, Mashhad University of Medical Sciences, Mashhad, IR Iran
}

\section{A R T I C L E I N F O}

Article type:

Original Article

Article history:

Received: 21 Mar 2012

Revised: 07 May 2012

Accepted: 15 May 2012

\section{Keywords:}

HTLV-I infections

Thalassemia

Polymerase Chain Reaction

\begin{abstract}
A B S T R A C T
Background: Human T-lymphotropic virus type I (HTLV-I) is one of the health threatening problems in endemic areas and can be transmitted by different routes such as blood transfusion. In order to correct chronic anemia in thalassemia subjects, they may need to get blood units per month. Thus, they are at risk of infection with blood-borne viruses such as HTLV-I.

objectives: In the present study, we investigated the prevalence of HTLV-I infection among high risk patients with thalassemia in north of Iran, Mazandaran.

Patients and Methods: A total number of 288 thalassemia patients including 151 females (52.4\%) and 137 males (47.6\%) with mean age of $21.45 \pm 6.6$ years were tested for HTLV-I Ig $\mathrm{G}$ and Ig $\mathrm{M}$ antibodies against gag proteins by enzyme linked immuniosorbent assay (ELISA). Polymerase chain reaction (PCR) test was applied to confirm HTLV-I infection in DNA samples of antibody positive subjects.

Results: In the primary screening by ELISA, 20 out of 288 (6.9\%) patients were positive for HTLV-I antibody. The PCR results confirmed that four out of 20 samples (1.4\%) were HTLV-I positive.

Conclusions: The seroprevalence of HTLV-I infection in patients with thalassemia in Mazandaran province compared to other parts of Iran was not too high; however, HTLV-I screening should be performed prior to blood transfusions to decline the risk of virus transmission in these patients.
\end{abstract}

Published by Kowsar Corp, 2013. cc 3.0.

Implication for health policy/practice/research/medical education:

The results of this study are useful for health policy and blood bank transfusion centres in HTLV-I control.

Please cite this paper as:

Ghaffari J, Kowsarian M, Mahdavi MR, Vahid Shahi K, Rafatpanah H, Tafreshian AR. Prevalence of HTLV-I Infection in Patients With Major Thalassemia in Mazandaran, North of Iran.Jundishapur J.Microbiol. 2013; 6(1): 57-60. DOI:10.5812/jjm.4702

\footnotetext{
${ }^{*}$ Corresponding author: Amir Reza Tafreshian, Inflammation and Inflammatory Diseases Research Canter, Faculty of Medicine, Mashhad University of Medical Sciences, Mashhad, IR Iran. Tel:+98-5118002376, Fax:+98-5118828560,E-mail:TafreshianAR1@mums.ac.ir

DOI: $10.5812 / j j \mathrm{jm} .4702$

(C) 2013 Ahvaz Jundishapur University of Medical Sciences; Published by Kowsar Corp.

This is an Open Access article distributed under the terms of the Creative Commons Attribution License (http://creativecommons.org/licenses/by/3.0), which permits unrestricted use, distribution, and reproduction in any medium, provided the original work is properly cited.
} 


\section{Background}

Human T-lymphotropic virus type1 (HTLV-1) is a type C virus which causes two main types of diseases: HTLV-I-associated myelopathy/tropical spastic paraparesis (HAM/ TSP) and adult T cell leukemia (ATL) (1, 2). Most of HTLV-I infected individuals remain asymptomatic throughout their lives and in a few subjects HTLV-I-associated diseases develop. The virus is endemic in different regions such as south west of Japan (3), the Caribbean islands (4), Central and South America (5), and some parts of Africa (6). We have previously reported that HTLV-I is endemic in north-east of Iran, particularly in the cities of Mashhad, Sabzevar, and Neishbour. The prevalence of HTLV-I infection in Mashhad, Neishbour, and Sabzevar is $2.1 \%, 3 \%$, and $1.6 \%$, respectively (7-9). However, the virus is less frequent in other parts of Iran including Urmia (0.34\%) in northwest and Chaharmahal-Bakhtiari $(0.62 \%)$ in south-west of Iran $(10,11)$.

The restricted distribution of HTLV-I infection is thought to be due to unique routes of virus transmission. Virus is transmuted through three important modes including blood transfusion, breast feeding, and sexual contact. Whole blood components, platelets, and packed red blood cells, but not fresh frozen plasma, are sources of virus transmission (12). The probability of seroconversion in a recipient of contaminated blood is about $44 \%$ (13). Thus, systemic screening of HTLV-I antibody in blood donors in endemic areas is necessary in order to prevent disease as well as to limit transmission of the virus. Thalassemia patients need infusion of four to six blood units per month and therefore the risk of blood-borne diseases caused by agents such as HTLV-I, Hepatitis B virus (HBV), Hepatitis $\mathrm{C}$ virus (HCV), and human immunodeficiency virus (HIV) is increased in these patients. Thalassemia is more prevalent in north and south of Iran (14). The overall prevalence of thalassemia in Mazandaran province, north of Iran, is about one patient per 1000 people (15). Studies in different parts of Iran such as south of Caspian sea and central and north-east of Iran reported that the rate of HTLV-I infection is high in thalassemia major patients (about 6\%) (16).

\section{Objectives}

The aim of this study was to examine the prevalence of HTLV-I infection in thalassemia major patients in north of Iran, Mazandaran, and to compare it with which occurs in healthy individuals of this province, and also with other published data in different parts of Iran.

\section{Patients and Methods}

\subsection{Population Study}

The study population included 288 thalassemia patients who attended Bu-Ali Sina hospital, Mazandaran Univer- sity of Medical Sciences for receiving periodical blood transfusion between September and November 2009. The patients consisted of almost all forms of thalassemia existing in this province. 151 patients were female (52.4\%) and 137 were male (47.6\%). The mean age of cases was 21.45 \pm 6.6 years. A questionnaire was provided for data collection on demographic, laboratory information, and risk factors. The study was approved by the ethics committee of Mazandaran University of Medical Sciences (MUMS) and informed consent was obtained from each subject. Six $\mathrm{ml}$ of blood was taken from each subject and serum and DNA were extracted.

\subsection{Serology and Confirmatory Test for HTLV-I Infection}

Enzyme linked immunosorbent assay (ELISA) (Dia Pro Diagnostic bio probe, Italy) was performed to screen anti HTLV-I Ig G and Ig M antibodies against gag proteins (gp 46-I and p 21-I) in serum samples according to the manufacture's instructions. QiaAmP DNA mini kit (Qiagen, Germany) was used according to the manufacturer's instructions to extract DNA HTLV-I proviral load genomes from $200 \mu$ of samples that scored HTLV-I-reactive in serological assays. DNA extracted from HuT-102 cell line (HTLV-I positive cell) was used as a positive control.

To confirm HTLV-I infection, PCR was carried out on all positive ELISA samples according to HTLV-I infection criteria (17) as we previously described (9). Briefly, PCR amplification was performed in a $25 \mu \mathrm{L}$ reaction including 20 $\mathrm{mM}$ Tris- $\mathrm{HCl}$ (pH 8.4), $100 \mathrm{mM} \mathrm{KCl,} 2 \mathrm{mM} \mathrm{MgCl}_{2}, 200 \mathrm{Mm}$ dNTPs, 0.5 U Taq DNA polymerase, $10 \mathrm{pmol} / \mu \mathrm{l}(1 \mu \mathrm{l})$ of each specific primer Tax sense (5'-AGGGTTTGGACAGAGTCTT-3'), Tax anti sense(Reversed) (5'- AAGGACCTTGAGGGTCTTA), LTR sense (5'-CATAAGCTCAGACCTCCGGG-3'), LTR anti sense (5'-GGATGGCGGCCTCAGGTAGG-3') and genomic DNA (50-100 ng). PCR consisted of initial denaturation at $94{ }^{\circ} \mathrm{C}$ for four minutes, followed by 35 cycles of $94{ }^{\circ} \mathrm{C}$ for 50 seconds, $60{ }^{\circ} \mathrm{C}$ for 50 second, $72{ }^{\circ} \mathrm{C}$ for one minute, and a final extension at $72{ }^{\circ} \mathrm{C}$ for five minutes. The products were visualized in a $2 \%$ agarose gel and stained by $5 \mu \mathrm{l}(0.5$ $\mathrm{mg} / \mathrm{ml}$ ) of ethidium bromide.

\section{Results}

Clinical, demographic, and laboratory findings of population study are shown in Table 1. From 288 thalassemia patients who attended for blood transfusion, 151 were female (52.4\%) and 137 were male (47.6\%). The mean age of cases was $21.45 \pm 6.6$ years. In the primary screening by ELISA, 20 (6.9\%) were positive for HTLV-I antibody (14 males and 6 females). All positive samples were confirmed by PCR and the results showed that only four males out of 20 subjects (1.4\%) were positive for HTLV-I. According to the results of PCR, the overall prevalence of HTLV-I infection in thalassemia patients in Mazandaran was $1.4 \%$. 


\begin{tabular}{ll}
\hline \multicolumn{2}{|c}{ Table 1. Demographic Characteristic of Thalassemia Patients } \\
\hline Age,y, mean \pm SD & $21.45 \pm \mathbf{6 . 6}$ \\
\hline Male, No. (\%) & $151(52.4)$ \\
\hline Female, No. (\%) & $137(47.6)$ \\
\hline Residence, No. (\%) & $153(53)$ \\
\hline City & $135(47)$ \\
\hline Rural & \\
\hline Material status, No. (\%) & $253(81.6)$ \\
\hline Single & $35(18.4)$ \\
\hline Married & \\
\hline Occupation, No. (\%) & \\
\hline Student & $81(28)$ \\
\hline Primary or High school & $8(4)$ \\
\hline University & $31(10)$ \\
\hline Public sector & $168(58)$ \\
\hline Jobless & \\
\hline History of surgery, No. (\%) & $95(32.98)$ \\
\hline Spelenctomy & $1(0.34)$ \\
\hline Cholescystectomy & $3(1.4)$ \\
\hline Spelnctomy and cholecystectomy & $2.1 \pm 2.6$ \\
\hline Age at diagnosis, $\mathbf{y}$, mean \pm SD & $2.7 \pm 3.6$ \\
\hline Age of transfused blood, $\mathbf{y}$, mean \pm SD & $390.3 \pm 182.2$ \\
\hline Received Blood (units),UI, mean \pm SD & $14(4.8)$ \\
\hline HCV (positive), No. (\%) & $2(0.69)$ \\
\hline HB Ag (positive), No. (\%) & - \\
\hline HIV (positive) & \\
\hline
\end{tabular}

\section{Discussion}

It is well known that HTLV-I not only induces HAM/TSP and ATL in a small proportion of HTLV-I asymptomatic carriers, but also is associated with other diseases such as cutaneous T cell lymphoma (CTCL), HTLV-I-associated arthropathy (HAAP), Graves' disease, uveitis, polymyositis, chronic respiratory diseases, lymphadenitis, and dermatitis (18). Iran in the middle of the so-called Thalassemia Belt is one of the countries which have high thalassemia carrier rate. It has been shown that thalassemia is more prevalent in the northern (Caspian sea) and southern areas of the country. The overall prevalence of thalassemia per 100,000 people ranges from three to 100 patients in different parts of the country (15). Thalassemia patients, who frequently receive blood, are one of the most high risk groups for HTLV-I infection $(19,20)$.

In the present study we examined the prevalence of HTLV-I infection in patients with thalassemia major in Mazandaran province which exhibits the highest rate of thalassemia in Iran (15). Using screening ELISA test, 20 (14 males and 6 females) out of 288 subjects had antibodies reactive with HTLV proteins (6.9\%). All of the reactive samples were examined by PCR to confirm the HTLV-I infection. Using both screening and confirmatory tests, the overall seroprevalence of HTLV-I in thalassemia patients was $1.4 \%$, all of them were male. Fourteen and two patients showed HBs Ag and HCV antibody, respectively, suggesting that blood-borne viruses are transmitted through blood transfusion. Our results showed that Although the prevalence of HTLV-I infection in normal population of north-east of Iran, Mashhad (2.1\%) and Sabzevar (1.6\%), is high and these regions have been recognized as new endemic regions of the virus, however the prevalence of the virus in patients who referred to Imam's Hospital Laboratory in Sari, capital of Mazandaran province, was $0.08 \%$ suggesting that HTLV-I is not prevalent in this region (21).

The rate of HTLV-I infection in thalassemia patients in Mazandaran is less than that was shown in Mashhad, Shiraz, Tehran, Bushehr, and Zahedan (16, 22-25). Surprisingly, Moradi et al. reported high rate of HTLV-I infection (4.449\%) among thalassemia patients in Golestan province neighboring Mazandaran province. They suggested that the rate of infection is associated with age and number of transfusion (26). The discrepancy in HTLV-I prevalence in whole population or even in multi-transfused patients in different parts of the country has not been fully understood. Different laboratory techniques, the studied population, and sample size might explain this issue. Although it has been shown that HTLV-I was more frequently observed in females compared to males, our results demonstrated that none of females showed antibodies against HTLV-I suggesting that blood transfusion might be the main route of HTLV-I infection in our population study.

In the present study, we could not find association between the number of blood units received by patients and HTLV-I infection. This might be due to small cases of confirmed HTLV-I by PCR. Determination of HTLV-1 proviral load and HTLV-I antibody titer would be useful to evaluate the immune response to the virus and developing HTLV-I-associated diseases. Furthermore, a parental history of HTLV-I would help to understand the route of HTLV-I infection in our study population. Further studies in the large sample size in patients with thalassemia major in Mazandaran province would help to confirm the data.

In conclusion, our study showed the prevalence of HTLV-I infection in thalassemia patients in Mazandaran is $1.4 \%$. Therefore, it is necessary to carry out a large seroepidemiological study in this part of Iran. Although the seroprevalence of HTLV-I infection in thalassemia patients in Mazandaran province compared to other regions of Iran is not too high, however, HTLV-I screening should be performed prior to blood transfusion to decline the risk of virus transmission in these patients.

\section{Acknowledgments}

We would like to thank Mazandaran University of Medi- 
cal Sciences for financial support.

\section{Financial Disclosure}

None declared.

\section{Funding/Support}

None declared.

\section{Authors' Contribution}

None declared.

\section{References}

1. Gessain A, Barin F, Vernant JC, Gout O, Maurs L, Calender A, et al. Antibodies to human T-lymphotropic virus type-I in patients with tropical spastic paraparesis. Lancet. 1985;2(8452):407-10.

2. Hinuma Y, Nagata K, Hanaoka M, Nakai M, Matsumoto T, Kinoshita KI, et al. Adult T-cell leukemia: antigen in an ATL cell line and detection of antibodies to the antigen in human sera. Proc Nat Acad Sci U S A. 1981;78(10):6476-80.

3. Morofuji-Hirata M, Kajiyama W, Nakashima K, Noguchi A, Hayashi J, Kashiwagi S. Prevalence of antibody to human T-cell lymphotropic virus type I in Okinawa, Japan, after an interval of 9 years. Am J Epidemiol.1993;137(1):43-8.

4. Blattner WA, Kalyanaraman VS, Robert-Guroff M, Lister TA, Galton DA, Sarin PS, et al. The human type-C retrovirus, HTLV, in Blacks from the Caribbean region, and relationship to adult Tcell leukemia/lymphoma. Int J Cancer. 1982;30(3):257-64

5. Reeves WC, Saxinger C, Brenes MM, Quiroz E, Clark JW, Hoh MW, et al. Human T-cell lymphotropic virus type I (HTLV-I) seroepidemiology and risk factors in metropolitan Panama. Am J Epidemiol.1988;127(3):532-9.

6. Saxinger W, Blattner WA, Levine PH, Clark J, Biggar R, Hoh M, et al. Human T-cell leukemia virus (HTLV-I) antibodies in Africa. Science. 1984;225(4669):1473-6.

7. Azarpazjhoo M, Hasanpoor K, Ghanbari M, Rezaee SA, Mashkani B, Hedayati-Moghaddam M, et al. HTLV-I prevalence in Northeastern Iran, Sabzevar; An epidemiologic based study and phylogenetic analysis. AIDS Res Hum Retroviruses. 2012

8. Farid R, Parizadeh M, Ghaffari J, Miri S, Nassirian A, Rafatpanah H. [Sero-epidemiological evaluation of HTLV-I infection in Neyshabour city]. Mashhad Med Univ J. 2005;47:417-24

9. Rafatpanah H, Hedayati-Moghaddam MR, Fathimoghadam F, Bidkhori HR, Shamsian SK, Ahmadi S, et al. High prevalence of HTLV-I infection in Mashhad, Northeast Iran: a population-based seroepidemiology survey. J Clin Virol. 2011;52(3):172-6.

10. Karimi A, Nafici M, Imani R. Comparison of Human T-cell Leukemia Virus Type-1 (HTLV-1) Seroprevalence in High Risk Patients
(Thalassemia and Hemodialysis) and Healthy Individuals from Charmahal-Bakhtiari Province, Iran. Kuwait Med J.2007;39(3):259.

11. Khameneh Z, Baradaran M, Sepehrvand N. Survey of the seroprovalence of HTLV I/II in hemodialysis patients and blood donors in Urmia. Saudi J Kidney Dis Transpl. 2008;19(5):838.

12. Rafatpanah H, Farid R, Golanbar G, Azad FJ. HTLV-I Infection: virus structure, immune response to the virus and genetic association studies in HTLV-I-infected individuals. Iran J Allergy Asthm. 2006;5(4)

13. Manns A, Wilks RJ, Murphy EL, Haynes G, Figueroa JP, Barnett M, et al. A prospective study of transmission by transfusion of HTLVI and risk factors associated with seroconversion. Int J Cancer. 1992;51(6):886-91.

14. Abolghasemi H, Amid A, Zeinali S, Radfar MH, Eshghi P, Rahiminejad MS, et al. Thalassemia in Iran: epidemiology, prevention, and management. J Pediatr Hematol Oncol. 2007;29(4):233-8.

15. Walker J. The heart in thalassemia. Eur Heart J. 2002;23(2):102-5.

16. Mansouritorghabeh H, Badiei Z. Transfusion-Transmitted Viruses in Individuals with $\beta$ Thalassemia Major at Northeastern Iran, a Retrospective Sero-Epidemiological Survey. Iran J Blood Cancer. 2008;1(1):1-4

17. Bangham CR. The immune response to HTLV-I. Curr Opin Immunol.2000;12(4):397-402.

18. Uchiyama T. Human T cell leukemia virus type I (HTLV-I) and human diseases. Annu Rev Immunol. 1997;15:15-37.

19. Chiewsilp P, Iamsilp W, Hathirat P. HTLV-I antibody screening in donated blood and thalassemic patients. J Med Assoc Thai.1993;76 (Suppl 2):103-5.

20. Covas D, Boturão Neto E, Zago M. The frequency of blood-born viral infections in a population of multitransfused Brazilian patients. Rev Inst Med Trop Sao Paulo. 1993;35(3):271-3.

21. Ghaffari J, Naghshvar F, Nazari Z, Farid R, Torabizadeh J, Madani F. Seroprevalence of human T-cell lymphotropic virus type 1 infection (HTLV1) in different patients in the north of Iran. Afr J Biotechnol. 2011;10(52):10752-5.

22. Anaraki M, Sadeghipour A, Vosogh P. Prevalence of HTLV-I in thalassaemic patients receiving continuously blood in Tehran. Med Iran Uni Med Sci. 2005;12(47):19-24.

23. Moradi A, Yaghub Nejad Z, Mohagheghi A, Shahraki S, Borgi A, Firouzkouhi M, et al. [Seroepidemiology of HTLV-1 in thalassemia patients from both Zahedan and Zabol in 1380]. Sci J Zanjan Uni Sci. 2003;43(11):43-7.

24. Pourkarim M, Khamisi G, Hajiani G. [Evaluation of seroepidimiologic of HTLV-I/II in patients who recurrent recipient of blood in Boshehr in 2003]. KHOON. 2005;2:99-104.

25. Sotoodeh M, Tabei S. Detection of human T-cell leukemia virus carriers in Thalassemia patients in Shiraz: A brief report. Iranian JMed Sci.1994;29:1-2.

26. Moradi A, Mansurian A, Ahmadi A, Ghaemi E, Kalavi K, Marjani A, et al. Prevalence of HTLV-1 Antibody among Major Thalassemic Patients in Gorgan (South East of Caspian Sea). J Appl Sci. 2008;8(2):391-3. 